\title{
HIIS SITES IN THE RESEARCH HISTORY OF ESTONIAN SACRED PLACES
}

\section{Tõnno Jonuks}

\begin{abstract}
The article gives an overview of the history of research of holy places which are called hiis in Estonia from the end of the 18th to the beginning of the 21 st century. The emphasis of the study is on academic treatments on the subject, and the article analyses the main research problems. The concept of hiis has been discussed to a lesser degree in the context of national ideology and identity, which nevertheless has left an important mark on academic studies.
\end{abstract}

Key words: hiis, history of research, holy grove, natural holy place

Sacred natural places, among which hiis sites (further on the semantics of the Estonian word hiis, see below) form the best known and the most thoroughly investigated part, and which are the most important archaeological places connected with Estonian religion, have started to attract multifarious scientific interest only recently (e.g., Remmel 1998; Jonuks 2007; Kütt 2007; Valk $2007 \mathrm{a}, \mathrm{b}, \mathrm{c}$ ). Although pagan sanctuaries have been the object of research for the clergy, politicians and historians already since the 18th century, more general and analytical studies are still lacking. The study of similar sites leaves much to be desired not only in Estonia, but natural holy places have emerged as subject of research during the past few years in the neighbouring countries as well (Bradley 2000, Brink 2001, Vaitkevičius 2004, Urtāns 2008).

Despite the paucity of academic studies there has been a long history of the treatment of hiis places and other non-Christian sites in Estonia, especially in the context of national identity. In this article I will try to offer a historiographical overview of sacred natural sites in Estonia and point out some aspects which play an important role in the studies, even though the historical background of the topic has often been neglected.

\section{FROM SOURCES TO STUDIES: EARLIEST REPORTS OF HOLY PLACES}

The earliest and probably the most famous description of a holy place dates from the beginning of the 13th century, when the chronicler Henry of Livonia described how two priests baptized people in Järva and Viru counties in 1220: 
They baptized three villages within Wierland. There was a mountain and a most lovely forest in which, the natives say, the great god of the Oeselians, called Tharapita, ${ }^{1}$ was born, and from which he flew to Oesel. The other priest went and cut down the images and likenesses which had been made there of their gods. The natives wondered greatly that blood did not flow and they believed the more in the priest's sermons. (HCL XXIV: 5).

The chronicler mentions holy places also in other contexts: for example, the same year the army of the Order met Oeselians in the village of Kareda in Central Estonia.

The Germans pursued them [i.e. Oeselians] from the village into the field, killing them through the fields up to their sacred grove (lucum ipsorum), stained their holy woods with the blood of many of their slain men (HCL XXIII: 9).

The description of priests cutting down "the images and likenesses" (imagines et similitudines) of their gods in the groves has caused some discussion. The expression is a loan from Genesis I:26: "Then God said, 'Let us make man in our image, in our likeness...' (faciamus hominem ad imaginem et similitudinem nostram)." Estonian folklorist Oskar Loorits has assumed that these figures did not depict gods but the souls of the dead (Loorits 1949: 178). It is the only text which describes the presence of figures in groves. Most descriptions refer to trees, while figures have been mentioned only in some folklore texts ${ }^{2}$ which have been written down at the beginning of the 20th century. It is likely that the figures of gods are secondary motifs in the texts and have been influenced already by written texts such as 19th-century textbooks, calendar articles and other National Romantic approaches.

The next text referring to holy places appears in Liber Census Daniae, written in 1241, which mentions a holy grove (lucus sanctus) in the vicinity of the village Wærkæla (Johansen 1933: 650). Today it is usually associated with the village of Võrkla in Viru County, North Estonia (Johansen 1933: 659) but it has also been linked to the village of Verkla in Harju County, North Estonia (Loorits 1957: 12).

Throughout medieval and modern times, holy places were mentioned only in connection with the descriptions of the local people who worshipped idols. Such texts only mention the holy sites and the fact that offerings were made there, reflecting mostly the veneration of trees, but also of stones, and other objects (see Sild 1937). In such descriptions trees have been considered the most important elements, which is also referred to by Latin (lucus sanctus, 
sancta silva) or German (heilige Hain) terms. Usually these texts reveal nothing other than these descriptions (see, e.g., Boecler 1854). The characteristic motif in most of these texts, however, is the proscription against damaging the holy place. This is also characteristic of the 19th- to 20th-century folklore in general. Thus, in the 16th century, the Livonian chronicler Balthasar Russow described pre-Christian Livonia:

And before Christianisation heathen Livonians held terrible rituals of superstition with the sun, the moon and the stars, also with snakes and other animals. They also considered some groves sacred, where no trees could be cut. And they believed that whoever cuts a tree or bush in this sanctuary would die. (Russow 1967: 20)

Similar descriptions have been presented in the 17th- and 18th-century texts (see Hupel 1774: 152-154, Hiärn 1794[1678]: 40, Feyerabend 2004[1797]). A description by Adam Olearius in his 1659 travelogue differs from the general taboos against damaging trees: "They do their devotions commonly upon hills, or neer a tree they make choice of to that purpose, and in which they make several incisions," they cut all branches of trunk up to the top, "bind them up with some red stuff, and there say their prayers, wherein they desire only temporal blessings" (Olearius 1669: 33).

Dann sie an unterschiedlichen Orten, sonderlich auff den Hügeln gewisse Bäume erwehlen, welche sie bis an den Sipssel aufschneiteln, mit rothen Bändern umbwinden, und unter denselben ihre abergläubische Wünsche und gebete thun, so nur zu erhaltung und vermehrung ihrer und der ihrigen zeitlichen Wolfahrt gereichet (Olearius 1663: 109).

Marju Torp-Kõivupuu (2007: 292) associates these trees with the tradition of Finnish karsikko-trees: during the funeral branches of a tree were entirely or partly cut off in the memory of the deceased. The examples which depart from the general and universal rule not to damage the place in any way need to be interpreted in a different manner and despite the common sacral sphere of meaning these need not be treated together with other holy and offering sites. As was pointed out to the author by Mare Kõiva, editor-in-chief of this journal, it is also interesting that the description of Adam Olearius resembles what has been told about Midsummer bonfires (leedu tuli) by inhabitants of the Muhu Island in the 20th century (Ränk 1935 and references therein). According to these accounts, branches were cut off the trunk of a birch, and bonfire material was heaped around the trunk. Indeed, the description of leedu fire better complies with the original Olearius' text, which is also not (directly) associated with funeral. However, despite the two similar analogies from the near past, 
trees in Olearius' description may represent a completely different tradition, which does not necessarily have to do anything with either funerals or the bonfire tradition.

At the end of the 18th century, together with the Enlightenment movement, a new period started in the research history, when holy places became the objects of study rather than being merely an element of pagan customs. The description of local religion and holy places by August Wilhelm Hupel, a priest of the church of Põltsamaa, could be mentioned as one of the earliest examples.

In some places there is one, in some there are many trees - mostly spruces; these are located on hills, fields, at springs, and other places. Peasants who are not afraid of punishment, bury their dead people in these places. It is strictly forbidden to go in these holy groves (abergläubischen Haine) and to worship these. Some landlords ordered peasants to cut the trees but with all the threats and admonitions have achieved nothing and eventually had to take an axe and give example to those fearful. Sacrificing wool, wax, yarn, bread, and other things is still a custom among them; they place these gifts in holy places or into tree hollows. Also, the rivers and springs receive gifts. (Hupel 1774: 153)

Several 17th- and 18th-century sources mention also stone crosses and chapels next to holy groves and stones as places of superstitious worship (Hupel 1774: 154, Jung 1910: 122). It is likely that for Lutheran priests who recorded these notes, it did not make any difference whether rituals which were not a part of official Lutheranism were conducted in non-Christian sacrificial places or at pre-Reformation Christian sites. Most likely not all places in Hupel's description can be considered holy places and having a similar function. It is very clearly mentioned in the text that people did bury their dead in the holy groves. However, since little evidence has been found about Early Modern burials in hiis sites known in oral lore (Valk 1995: 461), it is likely that in addition to the holy places, Hupel also described prehistoric graves or medieval and Modern Age rural cemeteries, where trees were also objects of veneration and damaging them was prohibited (see Moor 1998). Thus these are rather similar norms of behaviour which correlate with different sacral sites.

In the 17th century, the word hiis is mentioned in written sources for the first time. In 1694, a catechism was published in North-Estonian dialect, written after the original in South-Estonian dialect from 1684. Describing the violation of the First Commandment, 
I am the Lord your God, who brought you out of Egypt, out of the land of slavery. You shall have no other gods before me,

a sentence is added,

Kui Innimenne se Auu, mis Jummalalle ükspäine peab annetama, sellele annab, kennele se ei sünni; kui: Kujud palluma, ärasurnud Pühhad appi hüüdma, säetul Ajal umbusklikud Tootused vima, Ma-Emma ehk Maallusid tenima, mõnda Paika, Mäggesid, Kivvi, Hallikuid, Sauna-Leili, Hied ehk Puid Metsas pühhaks piddama, neile vahest Ohvrid vima, kahja teggema, ehk teisitau vörad Jummalad piddama (Cathechism 1694: 9).

[If a man gives worship, which is meant only for God, to those who are not worth it, if: idols are worshipped, dead Saints appealed to, gifts brought in special times, Earth Mother or Maa-alused ${ }^{\mathbf{3}}$ worshipped, some places, hills, stones, springs, steam of sauna, hiis or trees in the forest are considered holy, sacrifice is made to them or in other ways idols are served...]

The context reveals that it is likely that in the 17th century all these described beliefs were alive and this passage is written specifically against the worship of springs, stones, etc. Of course, the author of this publication, Johann Hornung must have been familiar with these beliefs and had used them as examples. Unfortunately, the original publication has not been preserved and it is uncertain whether the word hiis was mentioned also in the South-Estonian original. According to an acknowledged viewpoint the word hiis is connected with NorthEstonian dialect (Koski 1990: 406). This, however does not mean that the phenomenon of hiis occurs only in North-Estonia as it seems to be a concept characteristic of sea-related areas in Estonia (see Valk 2009), Finland (southern and southwestern part) and Karelian Aunus (see Koski 1967).

The word hiis appears also in the first Estonian Bible translation in 1739, where it has been used to translate the Hebraic word ashera, which stands for a fertility goddess, her idol, and her cult place (see more Koski 1967: 44-46). Hiis has been used to signify pagan cult buildings. As the word has been employed to refer either to a place or a person, Mauno Koski suggests that in the 18th century hiis in Estonian and Finnish could have meant both - a hiis site and the mythological beings living there (Koski 1990: 417).

Despite the fact that the word hiis has been mentioned in written sources already since the end of the 17th century, the term did not become established among researchers. Thus, the German parallel Hain was used through the 19 th century, leaving aside the word hiis that refers to a holy site and not only to forest or grove. 


\section{FROM A PAGAN SHRINE TO THE PILLAR OF NATIONAL IDENTITY: RESEARCH HISTORY OF THE 19TH AND EARLY 20TH CENTURY}

Next to the 18th-century Baltic-German researchers who were partial to the Enlightenment mentality, the emerging Estonian and Finnish national intelligentsia started to pay attention to the sacred places of the present and the past. For the first time, the word hiis and its etymology became an important issue. The oldest etymology, proposed for the word hiis, was presented by the Finnish priest Christfried Ganander in his Mythologia Fennica, published in 1789. Here the author connects the Finnish hiisi with the Ancient Egyptian goddess Isis (Ganander 1960[1789]: 14). This phonological association did not become established in the academic world but is still noteworthy as the first etymology of the word ever made. The interpretation proposed by Estonian poet Kristjan Jaak Peterson (FM 1822: 48) which connected hiis with giant (hiid in Estonian) gained much stronger ground. It is important to note that neither Ganander nor Peterson used hiis in the meaning of an offering place but only as a god or goddess who could be accompanied also by other supernatural creatures (hiie-hobune 'hiis horse', hiie-emand 'hiis mother', etc). The offering sites are referred to as uhripaika; also, in connection with witchcraft, graves from pagan periods are mentioned (FM 1822: 111). Hiidenkiukaat, aboveground stone graves, are according to both authors merely burial places of the past (Ganander 1960[1789]: 13, FM 1822: 110). The connection between giant and hiis has sporadically remained in use for a long time (Talve 1979, Annist 2005: 301). The interpretation of hiis as a creature and not as a holy place was used until the end of the 19th century: for example, Estonian folklorist Matthias Johann Eisen (1888) interpreted hiis rather as an evil fairy whose whereabouts became holy places to which offerings were brought.

The 18th- and 19th-century Balto-German researchers in Estonia used medieval and Early Modern Age chronicles as their main sources, the analyses of which became the most important subject in the study of Estonian history as a whole in the 19th century (see more Jonuks 2009 and references therein). Still, chronicles provide very little data about Estonian holy places and so other sources had to be used. Coinciding with the surge of National Romanticism and idealising of the Ancient Mediterranean and Nordic cultures, also Greek and Roman texts became important sources for parallels. The Balto-German historian and enlightener of Latvian origin Garlieb Merkel (1798) was the most influential scholar to pursue such a style. His interpretation of Estonian holy groves has remained very popular in the public history until now. According to Merkel, a holy grove is a nice oak grove, presumably on top of a hill where 
sacrifice to pagan gods was made. Since chronicles were the most important source material in these days, the above-mentioned text about "a most lovely forest" from the Chronicle of Henry of Livonia became one of the most fascinating sources to analyse. In 1836, the priest of Väike-Maarja church Georg Magnus Knüpffer published a paper in which he suggested that the hill and the forest described in the chronicle is the hill of Ebavere in the vicinity of VäikeMaarja in the Viru County, North Estonia (Knüpffer 1836).

Coinciding with the activity of Balto-German historians in the 19th century, the pantheon of Estonian prehistoric religion was established. The Estonian pantheon included gods like Vanemuine, Ilmarine, etc. and followed quite closely the classical Greek pantheon. One of the important initiators of this work was Ganander, whose study on the topic was translated into German by Kristjan Jaak Peterson (further on this see Jansen 1998, Järv 2001). Not only did the nobility of German origin support the Romantic movements, but also the Estonian intelligentsia, which had started to emerge in the 19th century, wished to show the high culture of pre-Christian Estonians. As the measure of culture was actually Christian and/or classical culture, depending on the scholars' preferences, the respective elements were "found" also in Estonian ancient culture and religion. As a result of these activities, a vision of Estonian pagan religion was formed in the 19th century and it was described as the cult of nature gods based on a polytheistic pantheon, which rituals were carried out in holy oak groves, where sacrifice was made to gods, and the dead were burned on pyres.

Such approach to religion, which clearly clashed with the dominating Christian culture, was easily incorporated into the creation process of Estonian national identity and from then on ideologists and politicians left their strong mark on the studies of the religion of the past and holy places (e.g., Reimann 1901). A classical Romantic example of prehistoric religion and holy places can be found in the work Eesti usk ('Estonian Religion') by Aleksander Treumann (?-1924) who writes under the pseudonym A. Heraklides (1908). The study is exceptional in its extreme claims, but characteristically shows what was considered important. The study, which is targeted either at children or a wider general audience, describes the justice and fairness of the past Estonian religion which was controlled by the supreme god Taara on the throne in a heavenly hall. Hiis groves have been described in very colourful terms; according to the description, these were old oak groves which were dedicated to Taara and originally situated in the vicinity of each village and town (Heraklides 1908: 15). The most famous hiis was situated on the territory of Tartu on the bank of the river Emajõgi, and has also given Tartu its name; ${ }^{4}$ there Estonians "did not serve their god with wide-eyed admiration or a stoop as some 'pious' 
ones nowadays do" (Heraklides 1908: 16). By the end of the 19th century an idealised approach to the sacred place was formed, in which an important element was quite clearly the purpose to rehabilitate the past and to show the former Estonian religion and its cultic places as something pure and natural.

From the mid-19th century onwards, organised collecting of folklore was started in Estonia and reached its peak by the end of the century (Laar et al. 1989, Laar 2006, Tedre 1989, Kalkun 2006). During the process, folklore scholars (Jakob Hurt, Matthias Johann Eisen, Jaan Jung) travelled around in the countryside and collected folklore but texts were sent to them also by the local intelligentsia such as teachers, priests, and educated peasants. On the basis of the material collected, the first serious studies on holy places were made. The main problem with the collected material was that the Romantic conception of sacred groves had already deeply settled in people's minds and it was constantly reemployed in textbooks and calendar texts of the period (see Viires 2001: 221). With these texts, the motifs of hiis were introduced again to the rural population and were adapted in folklore. The idealistic image was also supported by the ideological context at the time of national awakening, when Estonian religion as indigenous was set in opposition with Christianity as something new and violently imposed on people. So the 19th-century folklore-based concept of hiis and behavioural norms connected with it became the most important monuments of the ideology of independent Estonia in the past. It was characteristic of the period that researchers considered the contemporary FinnoUgrians, their religion, and ritual practices as a direct reflection of the Estonian religion prior to the 13th-century conquest, when Estonia was invaded by Danish, Swedish and German crusaders and the country was officially converted to Christianity. An illustrative example of this is the treatment which title translates as Finno-Ugric Worship during Pagan Times by Julius and Kaarle Krohn (1894). In this study, the Krohns directly associated the customs of contemporary Finno-Ugric tribes with pre-Christian religion in Estonia and Finland, leaving aside any discussion of differences between them or the dynamism of the religion during the millennium. Such a critique-less approach to the sources prevailed for almost a century, and focused mainly on the broader tradition of studying Estonian religion, in which the use of linguistic and folklore sources have been preferred. This approach obviously points to the use of ethnographic parallels of Finno-Ugric peoples (see Jonuks 2009).

At the end of the 19th and the beginning of the 20th century, folklore surrounding the concept of hiis was systematically studied for the first time and preliminary substantial results were presented (Jung 1879, Eisen 1920). Jaan Jung, a teacher with antiquarian interests claimed, relying on the results of his folklore collection, that hiis sites were places on hilltops where people 
came from far and wide to make sacrifices. In addition, every farm not only had its own hiis but also private sacrificial yards (Jung 1879: 37). By the 1890s, Jaan Jung had arrived at the most important result in hiis studies, when he collected information about (pre-)historic sites in Estonia and in the course of collecting, recorded many detailed descriptions of hiis places (Jung 1898, 1910).

In this period, scholars mostly held on to former views of holy places, according to which a hiis was considered to be a forest on top of a hill (Eisen 1920), although a much wider understanding of hiis was commonly spread as well. According to the latter, a hiis could have been an island in bogs, wet places, but also an area on completely flat ground. Also, scholars presented an overview of hiis folklore, emphasising mostly prohibitions connected to it: it was prohibited to cut trees, pick berries, curse, and exhibit any kind of inappropriate behaviour (Eisen 1920).

\section{THE BEGINNING OF ACADEMIC RESEARCH TRADITION: RESEARCH HISTORY IN THE FIRST HALF OF THE 20TH CENTURY}

Until the first part of the 20th century holy places were interpreted mostly as sacrificial places - an interpretation which obviously derives from contemporary folklore. All the sacrificial stones, either with or without artificial cupmarks (which have been attributed sacredness in folklore), were interpreted as having originally located in hiis (Viidalepp 1940: 38). Oskar Loorits (19001961), the most influential scholar of Estonian religion, had the same approach - hiis was explored together with other sacred sites known in folklore (sacrificial stones, yards, etc.) and the diversity of holy places was particularly stressed (Loorits 1935). At the same time, the study had undergone a change and next to gods and natural spirits as recipients of sacrifice, the spirits of the dead were introduced (Loorits 1932: 96, 1935: 297). A few decades later, while writing his major study about Estonian religion, Loorits directly connected hiis with the cult of the dead and fear of the dead in the original Uralic culture, and suggested that sacred groves were initially grave sites (Loorits 1957: 12). Unlike previous researchers, Loorits pointed to the motif in folklore, according to which people buried their dead in the holy groves and went to the groves to communicate with ancestors. Behind Loorits' idea - the connection of groves with the fear of the dead and ancestors - there is most likely a general trend in the early 20th-century European religious studies which considered death and the cult of the dead as the most important religious phenomena, especially in 
terms of prehistoric religions. Since then the connection between hiis and the cult of the dead remained a dominant interpretation until the 1990s when such a simplified approach attracted criticism (Valk 1995). In the studies of Loorits, especially in the earlier ones, hiis/folk religion and church/Christianity were clearly opposed: here, hiis was defined as an idealised natural sanctuary which "is not confined by stone walls" (Loorits 1932: 23).

Characteristically of the period, the dating of hiis and other natural holy sites was not considered a necessary research topic. The worship of stones, trees, and springs was originally connected with Finno-Ugric tribes and their religion but at the same time it was also associated with Germanic tribes (Loorits 1932: 97). Only sacrificial stones were more confidently connected with Germanic influences and so the cult of stones was dated to the Roman Iron Age (Viidalepp 1940: 22, 1941: 72). Based on undatable folklore, other holy sites were simply connected with prehistoric religion, without falling into further speculation. In this context it is important to note that everything nonChristian was believed to have been derived from pre-Christian times. Such approach, which excluded the non-Christian influences in medieval and modern times was, with few exceptions, predominant until the end of the 20th century.

\section{THE SECOND HALF OF THE 20TH CENTURY: THE REIGN OF LINGUISTICS}

After the Second World War, the study of religion in Estonia petered out, partly because of the prevailing ideological situation because the study of religion was complicated in the frames of scientific atheism (see Remmel 2008), but also because Loorits emigrated from Estonia, and the holy places were not included into the Estonian folklore studies in the Soviet period. The study of religion disappeared from the sphere of interest of Estonian researchers, but since religion could not be completely avoided in scholarly research, this meant that earlier treatments became fixed and without any discussion became unquestionable dogmas for decades.

All through the 20th century, Jung, Eisen, and especially Loorits whose often-cited works are only source publications, remained the leading authors in the field of religion and holy sites in Estonia. This approach was also employed by several local historians, who published texts and stories associated with certain localities (e.g., Hermann 1973, Relve 1982), which, however, lacked a generalising and analysing character. 
Nevertheless, the analysis of Saunja hiis site by biologist and local historian Gustav Vilbaste (1947) should be mentioned in this context because it introduces an entirely new source in the analysis of hiis sites - maps of different periods. On the example of a 1693 map, Vilbaste successfully identified the location of a hiis site, mentioned in oral lore, and the map shows a fence surrounding the said grove. The latter is important because several texts of hiis lore mention that holy sites were enclosed with fences or walls which function was to protect the holy places. Unfortunately, historical maps have been neglected in the studies of holy sites until today. One of the reasons is that the majority of the maps are dated to the 19th century when non-Christian holy sites were no longer marked on maps. However, on the basis of the 17th- and 18th-century maps it should be possible to identify several hiis sites mentioned in more recent folklore, and this way, conclusions can be made about the mutual relationship of hiis places, settlement centres, and burial sites. Fences that once may have surrounded holy places can be studied with archaeological methods. It is widely accepted that there is no cultural layer at the sites of holy places and stray finds are rare as well, which makes these difficult to study. So far there has been only one case in which a stone fence has been excavated at a holy hill identified in folklore, although even in this case the dating of the fence and its purpose remained unclear (Jonuks: in press).

Since studying of religion and holy places was more complicated in Estonia, the most important and for Estonian researchers also the most influential studies were made in Finland. The most important among these was a monograph by Mauno Koski (1967, 1970, article on the same subject in English 1990). Koski's main research subject is the semantics of the Estonian and Finnish word hiis and lore about hiis sites. According to Koski, who was strongly influenced by Loorits (1957), holy groves were originally graves, or were in the same sacral sphere as graves, and only later the groves developed into nonChristian cult places (Koski 1967: 101). The local landscape was of crucial importance in the choice of the location for the hiis, and according to Koski the most prominent landscape elements were selected (e.g., hills, mountain tops, etc). So, two semantic levels of hiis places will be revealed - first, a burial site, and second, an exceptional natural place, a sacrificial site (Koski 1967: 101).

According to Koski's interpretation, the original centre of the hiis tradition was in North and West Estonia and Southwest Finland, where it had the meaning of "a cult place where the dead, the spirits of the ancestors, were worshipped" (Koski 1990: 432).

Koski was also the first to date hiis places - he suggested that the end of the prehistoric period in 800-1100 AD was the time when hiis was a cemetery and a cult place of one village or a group of villages (Koski 1967: 85). He saw the 
connection between the hiis sites and villages from the end of prehistory and the Middle Ages as evidence to his argument (Koski 1990: 405). Since medieval times a shift in the meaning has taken place, and as a result, the hiis tradition no longer involved so many elements from the cult of death and other ritual activities were practised (Koski 1990: 432).

The relatively late dating of the hiis sites did not comply with the Bronze and Iron Age stone graves found in many Finnish and Estonian hiis places. As hiis sites were situated outside villages at the time, according to Koski the overlapping was partly accidental, but partly owing to the fact that stone graves were integrated in the hiis tradition (1990: 429). Therefore, also stones and cairns played an important role in the hiis tradition. Still Koski leaves open the possibility that the term hiis and its semantic meaning may have been used already before, "but we cannot determine at which point the term first came into use" (Koski 1990: 409).

Shorter studies on the subject of hiis have been written by other researchers. On the basis of Finnish folk tradition, the Estonian cultural historian Ilmar Talve (1979) has suggested that hiis initially denoted a (holy) grove or its guardian spirit, then forest fairies, and finally a creature independent of a certain place who is named jättiläinen or vuorenpeikko in western Finland, piro in eastern Finland, and who could be considered akin to Estonian giant ogre. In addition, Talve emphasises the role of hiis sites as communal ceremonial sites (1979: 208). It should be borne in mind that Estonian and Finnish hiis traditions are relatively different (see more Koski 1967). In the Finnish tradition, hiis has rather been associated with something strange and hostile and probably through this association the link to giant ogres has strengthened. However, the principal elements of the Estonian hiis tradition are the protection and inviolate keeping of hiis sites and the connection with giants is almost missing. Also, Estonian ethnologist Gustav Ränk (1980) has used folklore as the main source in his analysis of the creatures of hiis.

Despite the extensive and versatile study of Koski, the second half of the 20th century can be considered the period of linguists, even though mostly small, numerous studies of both the etymology of the hiis word as well as the linguistic semantic spheres have been published during this period. Valdek Pall in Estonia invited people to collect and send hiis related words to the Institute of Language and Literature (Pall 1963), proposing in his call the semantic spheres of hiis words collected thus far. According Pall, hiis sites were associated with five meanings, most of which are connected with trees: (1) a big forest, (2) a grove, thicket, (3) a young forest, (4) a single big tree, and (5) supernatural creatures to whom offerings were made. Apparently the meanings 
derive from folklore and, again, different aspects of hiis landscapes are emphasised here. Also, in Finland hiis has been commonly thought of as a (holy) forest (e.g., Haavio 1963). A relatively similar tradition continued until the end of the 20th century, an example of which might be the categorisation of hiis sites on Saaremaa Island and the Lääne County in West Estonia suggested by Marja Kallasmaa (2003: 106): (1) a wider area, (2) a swampy basin, 3) a small meadow, a clearing, 4) a low hill, 5) a bog island, 6) a forest, grove, 7) a higher hill.

The linguistic trend was also predominant in Finland where the etymology of the word became the main problem (see Bergsland 1964, Koski 1967, Hofstra 1988, Anttonen 1992). The etymological trends presented by several different authors can be grouped in three main branches. Researchers who considered hiis to be a Finnic word have interpreted it, on the basis of hiis lore, as a holy forest or a grove (Koski 1967, Mägiste 1983: 344). At this point it is important to note that the word hiis is not connected to any other word with the meaning of forest or grove. First and foremost, the word means a place on the landscape where rules of holiness and bans on damaging nature apply, and so the majority of hiis sites have been forested. Thus the connection of forest and hiis site is clear but the original meaning of hiis was not necessarily related to forest. Two original Sámi words - sii'dâ and siei'de - have been pointed out as another major course of study (see Bergsland 1964). The connection of hiis with siei'de, meaning 'sanctuary', 'altar' or 'idol', is supported by semantic compatibility both refer to a holy site. However, phonetic aspects have turned out to be problematic and a linguistic historical development from siei'da to hiis is unlikely. The other original word from the Sámi language, sii'da, stands for 'community', 'village with surrounding pastures and reindeer herds' and is not connected with the sphere of holiness at all, although phonetically it is more closer to hiis.

Two possible original words have been suggested also from Germanic languages - *sīdon- and *hiiði / hiibi. The former means 'side' and marks 'part', 'direction', 'coastal area' as a landscape term (Hofstra 1988: 19). As to this word, liminality and the notion of border that coincides with the concept of hiis and holiness have been emphasised (see Anttonen 1996). Thus hiis has "initially been a term explaining and characterising the physical essence of a specific place" (Anttonen 1992: 2523). The second possible original Germanic word *hiiði/hiipi means 'a nest', 'a place to rest', and is thereby connected with grave (Koski 1967). At the same time it has the meaning of a stony hill, which coincides with the geography of many hiis sites (see also Jonuks 2007). 


\section{RECENT DECADES: HIIS AS THE OBJECT OF ACADEMIC RESEARCH}

Estonian scholars have mostly avoided the subject of hiis following the major study by Oskar Loorits. On the one hand, it is definitely connected with the condemning of religious studies in the Soviet period of scientific atheism. On the other hand, it is related to the public attitudes towards hiis and the ideological pressure of the Soviet period, which implied that hiis marked the religion of ancient and independent Estonians, and no doubt, left its trace on the studies.

Partly as a continuation of earlier traditions (Viires 1975), holy trees were studied and the study led to the conclusion that sacredness can be ascribed to almost all species of trees (Puss 1995). There have been various reasons for attributing sacredness to a tree, from the special growing place of the tree to its unusual appearance. However, in folk tradition a quarter of all texts about holy trees mention oak. At this point it is important to consider the influences of the 19th-century National Romantic literature and its role in the development of folk tradition.

Hiis sites were first associated with archaeological material by Heiki Valk (1995) who, in the framework of a broader study, pointed out that there is no essential connection between hiis sites and graves (discussing the village cemeteries of the end of the prehistoric period and the Middle Ages). Disagreeing with Oskar Loorits and Mauno Koski, he suggested that hiis places have been completely separate sites on the landscape and their initial semantic field need not have been connected with the dead and the burial site at all (Valk 1995: 461). Veikko Anttonen (1992: 2521) emphasises as well that accepting the hiis as a holy place from the standpoint of the cult of the dead has expired and while choosing the hiis site, the milieu dominance of the landscape is not connected with the choice of the site for a cemetery but with the category of holiness (Anttonen 1992: 2525). The territory declared holy may have been used as a cemetery.

It is similarly obvious that hiis and the sphere of death culture cannot be separated, although hiis sites are not necessarily directly associated with graves. For example, Estonian folklorist Mari-Ann Remmel, in her monograph of hiis places, the only study written by an Estonian researcher so far, refers to the traditional motif of feeding the souls of the dead in hiis (Remmel 1998: 18). At the same time this behaviour may appear without burying into the hiis sites. The Udmurts, for example, have commemorated their dead in several places, including the lud-complex - their analogue to hiis - although luds are not used for burying (Lintrop 2003: 190). The connection of the traditions of 
hiis and death is emphasised by Argo Moor (1998: 50), who has referred to similar customs and rules that are valid both at holy sites as well as in burial places.

Explanation of the principles for selecting a place for the hiis has been an important aspect of the studies of hiis sites. Earlier researchers have only briefly dwelled on the choosing of hiis places, emphasising the prominence of landscape. In the 1990s, the concept of anomaly, distinction from the surroundings, conspicuousness and the presence of natural border was proposed, relying primarily on the concepts of holiness presented by Mauno Koski and Veikko Anttonen (e.g., Moor 1998: 49). Thus a hiis may be both a hill as well as a depression, since both own a clearly perceivable natural border. A somewhat similar approach of holy sites has been proposed in prehistory wider, and this emphasises the prominent landscape which may have been perceived as holy and powerful (Lang 1999). A new perspective was offered by Heiki Valk (2007a), who suggested that the selection of hiis sites might have been motivated by energetic fields that cannot be studied yet. In connection with latter also the anomaly of landscape or flora (trees with branches growing up- or downwards, conspicuous plant communities, etc.) might have played a role in the choice of holy sites.

Next to their location, the dating of hiis sites has captured less attention. It is clear that since the majority of sources available for hiis sites are formed by undatable folk tradition, all speculations on the topic are very complicated, especially because until now hiis sites have not been archaeologically studied. Therefore an ahistorical approach has remained predominant (cf. Insoll 2007: 141) and hiis and other holy sites are considered to belong to some timeless past. At the same time, it has been suggested that their age is centuries if not millennia old, though these arguments are mostly ungrounded. It is apparent that the general name hiis, holy, or offering place, discloses sites from different periods, some of which may be of old origin, while others may have been taken into use relatively lately (see Valk 2007b: 144ff). However, it may be possible to develop a system of folkloristic hiis sites which would comprise places of varying topography and accompanying sites. Accordingly, it is possible to distinguish a possibly older group of sites which are situated on naturally more spectacular hills and which can be associated with stone graves, and the beginning of the use of which may date from the 1st millennium BC (see Jonuks 2007). The religious meaning of these places was probably closely related to the death culture. In case of the hiis sites which have been taken into use later (i.e. in different religious context), natural prominence has not been a decisive criterion although anomalous places have been preferred. Furthermore, these places also lack a (direct) connection with graves. 
In addition to the discussed aspects the hiis discussion in the last decade is characterised by issues of their protection (see Kaasik 2001, Valk 2007b, c and references therein). Under the leadership of Maavalla Koda, an organisation that unites adherents of Taara religion and Estonian native religion, a conference on the topic joining different subjects was held in 2005 (see Valk 2007c). Numerous articles which concentrate on protection issues, especially against industrial or tourist development at hiis sites (e.g., in the cases of Kunda, Paluküla, Panga, etc.), have also been published in national media. Related to the latter issues, the use of hiis places in the context of national identity can be observed. Since the first surge of national awakening in Estonia, hiis has become the symbol of free and native cultural Estonia and Estonianness which, responding to stronger or lower pressure of the surrounding (political/ideological) context, has emerged every now and then. From the concepts that are rooted in the 19th-century National Romanticism, a strong ideological pressure to study the phenomenon of hiis and other natural holy sites has formed. During the past decade, especially in digital and spontaneously emerged media (weblogs, websites, comments to online newspaper articles, etc.), the role of hiis in Estonian indigenous culture and significance in preserving Estonianness has come to be emphasised, similarly to the 19th-century period of national awakening. Sometimes such claims assume very colourful and extreme positions. Though, it should be noted that for the most people who protect hiis or consider it important, these places seem to be rather powerful and ideological monuments from the past and from their predecessors, and they do not use the places on religious purposes. Although such sources seem to be far away from academic research it is still important to notice and remember these because of their potential influence on modern folklore and also on academic studies.

\section{CONCLUSION}

Hiis sites and other natural holy sites have captured the interest of researchers of different background ever since the period of Enlightenment at the end of the 18th century and the first surge of national awakening in Estonia in the 19 th century. The role of single eminent researchers who have developed the understanding of non-Christian holy sites has continued to be followed. Strangely enough, despite the significance of holy sites on national identity during the last couple of centuries, it is only by the beginning of the 21st century that natural holy sites have received a more systematic and multidisciplinary attention. However, a long step is yet to be taken towards a more problem- 
centred interdisciplinary study of the topic. Hopefully this approach helps to revive the use of sources, especially the main source - folk tradition - which until now has been often exploited without critical analysis. Still, next to folk tradition, other possible sources and disciplines from archaeology and cartography to ecology should be used more often than before. It is also important to note that holy sites emerge and are used in particular religious contexts. Too often studies have focused only on the phenomenon of hiis, neglecting the wider background, and thus the whole discourse remains oversimplified. With this, the problem of dating the holy places together with localising and inventory should be the topic in focus in the years to come.

\section{ACKNOWLEDGEMENT}

The article has been written with the support of state programme SF0030181s08.

\section{NOTES}

1 The god Tharapita has been discussed in several studies (see Masing 1939, Viires 1990, Sutrop 2004 and references therein).

${ }^{2}$ For example, an account recorded in the village of Männiku in Viru-Nigula parish: Beside Männiku village there is an alder brush on the seashore. This is called Hiie lepik (Hiis Alder). There used to be a hiis in the old times. There were big figures of idols and people were worshipping these and sacrifice was made for to the biggest figure (ERA II 216, 179 (9)).

${ }^{3}$ Maa-alused - in Estonian mythology elflike creatures, who were believed to reside underground.

${ }^{4}$ According to popular etymology, the name of Toomemägi, the hill in the centre of Tartu, Estonia derives from toomingas ('bird cherry') and a hypothetical holy grove of bird cherry there. The name actually comes from the medieval Dome Church on the hill.

5 In addition to the anomaly of landscape, flora (trees with branches growing up- or downwards, conspicuous plant communities, etc.) or energetic anomaly might have played a role in the choice of holy sites. Considering the large number of hiis sites that are not situated in prominent landscape localities, alternative interpretations are well justified.

\section{ARCHIVE SOURCES}

ERA - Estonian Folklore Archives 


\section{REFERENCES}

Annist, August 2005. Friedrich Reinhold Kreutzwaldi “Kalevipoeg”. [Kalevipoeg by Friedrich Reinhold Kreutzwald.] Tallinn: Eesti Keele Sihtasutus.

Anttonen, Veikko 1992. "Püha" mõiste rahvausundi uurimises. [The Concept 'Holy' in Studying Folk Religion.] Akadeemia, Vol. 12 (45), pp. 2514-2535.

Anttonen, Veikko 1996. Ihmisen ja maan rajat: "Pyhä" kulttuurisena kategoriana. [Corporeal and Territorial Boundaries. The Sacred as a Cultural Category.] Helsinki: Suomalaisen Kirjallisuuden Seura.

Bergsland, Knut 1964. Suomen hiisi. [Finnish Hiisi.] Virittäjä. Kotikielen Seuran Aikauslehti. Helsinki, No. 3 (68), pp. 242-248.

Boecler, Johann Wolfgang 1854. Der Ehsten abergläubische Gebräuche, Weisen und Gewohnheiten von Johann Wolfgang Broecler, weilan Pastor zu Kusal Ehstland und des Consistorii in Reval Assessor. Mit auf die Gegenwart Bezüglichen Anmerkungen beleuchtet von Dr Fr. R. Kreutzwald. St Peterburg: Buchdruckerei der Kaiserlichen Akademie der Wissenschaften.

Bradley, Richard 2000. An Archaeology of Natural Places. London \& New York: Routledge. Brink, Stefan 2001. Mythologizing Landscape. Place and Space of Cult and Myth. In: Kontinuitäten und Brüche in der Religionsgeschichte. Festschrift für Anders Hultgård zu seinem 65. Geburtsdag am 23.12.2001. Berlin \& New York: Walter de Gruyter, pp. 76-112.

Catechism 1694 = Katekismus. Önsa Luterusse Laste Öppetus Lühhidelt Pühha kirja järrele ärra-sellitud, ning küssemisse ja kostmisse kombel kokko säetud. Jummala auuks, ning temma koggudusse Kasvuks. [Cathecism. The Teachings for the Blessed Lutheran Children Summarised from the Holy Bible and Composed in the Form of Answers and Questions. In Honour of God and for the Growth of His Congregation.] Riga: Druckts Johann Georg Wilcken.

Eisen, Matthias Johann 1888. Elu pärast surma. Hiied ja Perma. Kolm kujutust ennemuistsest ajast. [Life after Death. Hiis and Perma. Three Conceptions from the Ancient Time.] Tartu: K.A. Hermann.

Eisen, Matthias Johann 1920. Esivanemate ohverdamised. [The Offerings of Ancestors.] Tartu: Eesti Kirjanduse Selts.

Feyerabend, Karl 2004[1797]. Kosmopoliitilised rännakud. Kiri Eestimaalt 1797. [Cosmopolitical Journeys. A Letter from Estonia in 1797.] Transl. and afterword by Urmas Sutrop. Tallinn: Eesti Keele Instituut \& Eesti Keele Sihtasutus.

FM $1822=1822$. Christfrid Ganander's Thomasson's Philos. Mag. Finnische Mythologie Aus dem Schwedischen übersetzt, völlig umbearbeitet und mit Anmerkungen versehen von Christian Jaak Peterson, Literat in Riga. Beiträge zur genauern Kenntniss der ehstnischen Sprache, 14. Pernau: Johann Heinrich Rosenplänter, pp. 2-114.

Ganander, Christfrid 1960[1789]. Mythologia Fennica. Helsinki: Suomalaisen Kirjallisuuden Seura.

Haavio, Martti H. 1963. Heilige Haine in Ingermanland Helsinki. Helsinki: Suomalainen Tiedeakatemia.

HCL $1961=1961$. The Chronicle of Henry of Livonia. A Translation with Introduction and Notes by James A. Brundage. Madison: The University of Wisconsin Press. 
Heraklides, A. [Aleksander Treumann] 1908. Eesti usk. [Estonian Religion.] Tallinn: Mõte.

Hermann, Uno 1973. Miks Pühajõge peeti pühaks? [Why was Pühajõgi Considered Holy?] Eesti Loodus. Vol. 2, pp. 108-110.

Hiärn, Thomas 1794[1678]. Thomas Hiärns Ehst-, Liv- und Lettländische Geschichte. Nach der Originalhandschrift. Erster Theil. Jelgava (Mitau): Johann Magnus Wehrt.

Hofstra, Tette 1988. Hiisi: uusi ehdotus sen germaanisesta alkuperästä. [Hiisi: A New Hypothesis of its Germanic Origin.] In: S.-L. Hahmo, T. Hofstra, A.D. Kylstra \& O. Nikkilä (eds). Omaa vai lainattua. Itämerensuomen germaanisiin lainasanoihin liittyviä kirjoitelmia. Helsinki: Suomalaisen Kirjallisuuden Seura, pp. 17-23.

Hupel, August Wilhelm 1774. Topographische Nachrichten von Lief- und Ehstland. Bd I. Gesammelt und herausgegeben durch August Wilhelm Hupel. Riga: Johann Friedrich Hartknoch.

Insoll, Timothy 2007. 'Natural' or 'Human' Spaces? Tallensi Sacred Groves and Shrines and Their Potential Implications for Aspects of Northern European Prehistory and Phenomenological Interpretation. Norwegian Archaeological Review, Vol. 40, No. 2, pp. 138-158.

Jansen, Ea 1998. Muinaseesti panteon: Faehlmanni müütide roll eestlaste rahvusteadvuses. [Estonian Ancient Pantheon: The Role of Faehlmann's Myths in Estonian National Consciousness.] Keel ja Kirjandus, Vol. 12, pp. 801-811.

Johansen, Paul 1933. Die Estlandliste des Liber Census Daniae. Reval: Wassermann.

Jonuks, Tõnno 2007. Holy Groves in Estonian Religion. Estonian Journal of Archaeology, Vol. 11, No. 1, pp. 3-35.

Jonuks, Tõnno 2009. Eesti muinasusund. [Prehistoric Religions in Estonia.] Dissertationes Archaeologiae Universitatis Tartuensis 2. Tartu: Tartu Ülikooli Kirjastus.

Jonuks, Tõnno (in press). Hiis Sites in the Parishes of Rapla and Juuru. In: Muinasaja Teadus, Vol. 21.

Jung, Jaan 1879. Eesti rahwa wanast usust, kombedest ja juttudest. Wälja annud J. Jung. [About Old Beliefs, Customs and Tales of Estonians. Published by J. Jung.] Kodu-maalt, Vol. 6. Tartu: H. Laakmann.

Jung, Jaan 1898. Muinasaja teadus Eestlaste maalt, II. Kohalised muinasaja kirjeldused Liiwimaalt, Pernu ja Wiljandi maakonnast. [Research into Ancient Times, Part 2. Descriptions of Ancient Sites in Livonia, in Pärnu and Viljandi counties.] Jurjev: A. Grenzstein.

Jung, Jaan 1910. Muinasaja teadus eestlaste maalt, III. Kohalised muinasaja kirjeldused Tallinnamaalt. [Research into Ancient Times, Part 3. Descriptions of Ancient Sites in North Estonia.] Eesti Kirjanduse Seltsi Toimetused, IV. Tallinn:

A. Buschi raamatukaupluse kirjastus.

Järv, Risto 2001. Kristfrid Gananderi "Mythologia Fennica" saksakeelsest tõlkest. [About the German Translation of Kristfrid Ganander's Mythologia Fennica.] Keel ja Kirjandus, Vol. 3, pp. 173-180.

Kaasik, Ahto 2001. Hiitest. [About Hiis Sites.] Available online at http://www.maavald.ee/ maausk.html?rubriik=20\&id=24\&op=lugu, last accessed in August 2009.

Kalkun, Andreas 2006. Rahvaluulekoguja kui looja. Seto pärimuse representeerimisest Jakob Hurda "Setukeste lauludes". [Folklore Collector as a Creator. About the 
Representation of Seto Folklore in Jakob Hurt's Seto Songs.] In: A. Lintrop (ed.) Regilaul - esitus ja tõlgendus. Eesti Rahvaluule arhiivi toimetused / Commentationes Archivi Traditionum Popularium Estoniae, 23. Tartu: Eesti Kirjandusmuuseum, pp. 67-84.

Kallasmaa, Marja 2003. Läänemurde loodus- ja viljelusnimed. [Nature and Agricultural Names in West-Estonian Dialect.] Tallinn: Eesti Keele Instituut \& Eesti Keele Sihtasutus.

Knüpffer, Georg Magnus 1836. Der Berg des Thorapilla: Ein historischer Besuch. Das Inland: Eine Wochenschrift für Liv-, Esth- und Curländische Geschichte, Geographie, Statistik und Litteratur, No. 22, pp. 361-366.

Koski, Mauno 1967. Itämerensuomalaisten kielten hiisi-sanue. Semanttinen tutkimus, I. [The Word Hiis in Baltic-Finnic Languages. Semantic Study, 1.] Turun yliopiston julkaisuja. Sarja C. Scripta lingua Fennica edita. Turku: Turun yliopisto.

Koski, Mauno 1970. Itämerensuomalaisten kielten hiisi-sanue. Semanttinen tutkimus, II. [The Word Hiis in Baltic-Finnic Languages. Semantic Study, 2.] Turun yliopiston julkaisuja. Sarja C. Scripta lingua Fennica edita. Turku:Turun yliopisto.

Koski, Mauno 1990. A Finnic Holy Word and its Subsequent History. In: T. Ahlbäck (ed.) Old Norse and Finnish Religions and Cultic Place-Names. Based on papers read at the Symposium on Encounters between Religions in Old Nordic Times and on Cultic Place-Names held at Åbo, Finland, on the 19th-21st of August 1987. Åbo: The Donner Institute for Research in Religious and Cultural History, pp. 405-440.

Krohn, Julius 1894. Suomen suvun pakanallinen jumalanpalvelus: neljä lukua Suomen suvun pakanallista jumaluusoppia. [Finno-Ugric Worship during Pagan Times.] Helsinki: Suomalaisen Kirjallisuuden Seura.

Kütt, Auli 2007. Maarahva pühade puude ja puistutega seotud käitumisnormid. [Behavioural Norms Related to Sacred Trees and Groves of Estonia.] In: H. Valk (ed.) Looduslikud pühapaigad. Väärtused ja kaitse. Õpetatud Eesti Seltsi Toimetised, 36. Tartu: Õpetatud Eesti Selts, pp. 185-212.

Laar, Mart; Saukas, Rein \& Tedre, Ülo. 1989. Jakob Hurt 1839-1907. Tallinn: Eesti Raamat.

Laar, Mart 2006. Äratajad. Rahvuslik ärkamisaeg Eestis 19. sajandil ja selle kandjad. [Awakers. National Awakening in Estonia in the 19th Century and Its Transmitters.] Tartu: Grenader.

Lang, Valter 1999. Kultuurmaastikku luues. Essee maastiku religioossest ja sümboliseeritud korraldusest. [Creating the Cultural Landscape. An Essay on Religious and Symbolic Organisation of the Landscape.] Estonian Journal of Archaeology, Vol. 3, No. 1, pp. 63-86.

Lintrop, Aado 2003. Udmurdi usund. [Udmurt Religion.] Tartu: Eesti Rahva Muuseum. Loorits, Oskar 1932. Eesti rahvausundi maailmavaade. [The Worldview of Estonian Folk Religion.] Tartu: Eesti Kirjanduse Selts.

Loorits, Oskar 1935. Mulgimaa ohvrikohad. Die Opferstätten in Mulgimaa. Kaleviste mailt (Õpetatud Eesti Seltsi Kirjad III). Tartu: Õpetatud Eesti Selts, pp. 226319 .

Loorits, Oskar 1949. Grundzüge des Estnischen Volksglaubens, 1. Skrifter utgivna av Kungl. Gustav Adolfs Akademien för folklivsforskning, 18:1. Uppsala: Lundequistska Bokhandeln; Köpenhamn: Munksgaard. 
Loorits, Oskar 1957. Grundzüge des Estnischen Volksglaubens, 3: 1. Skrifter utgivna av Kungl. Gustav Adolfs Akademien för folklivsforskning, 18:3, 1. Uppsala: Lundequistska Bokhandeln; Köpenhamn: Munksgaard.

Masing, Uku 1939. Taara päritolust. [About the Origin of Taara.] Usuteaduslik ajakiri No. 1, pp. 1-17.

Merkel, Garlieb Helwig 1798. Die Vorzeit Lieflands: ein Denkmal des Pfaffen- und Rittergeistes. Bd I. Berlin: Voss.

Moor, Argo 1998. Hingepuu. Vanade mü̈̈tide jälgedes. [The Tree of Soul. Tracing the Old Myths.] Tartu: Elmatar.

Mägiste, Julius 1983. Estnisches Etymologisches Wörterbuch, Vol. 2. Helsinki: FinnischUgrische Gesellschaft.

Olearius, Adam 1663. Adam Olearii Außführliche Beschreibung der Kundbaren Reyse nach Muscow und Persien... Ausgabe: Jetzo zum dritten und letzten mahl correct heraus gegeben. Schlesswig: Holwein.

Olearius, Adam 1669. The Voyages and Travells of the Ambassadors Sent by Frederick, Duke of Holstein, to the Great Duke of Muscovy and the King of Persia... London: Printed for John Starkey and Thomas Bassett.

Pall, Valdek 1963. Kas teie kodumurdes esineb sõna hiis? [Is There the Word Hiis in Your Local Dialect?] Questionnaire. Kodumurre, 6. Tallinn: Eesti NSV Teaduste Akadeemia Emakeele Selts, pp. 41.

Puss, Fred 1995. Puudega seotud pärimused ja traditsioonid Eesti rahvakultuuris. [Folklore and Traditions related to Trees in Estonian Folk Culture.] Available at http://www.hot.ee/fpuss/bibl/proseminar.html, last accessed in August 2009.

Reiman, Villem 1901. Eesti muinasusk. Kõne. [Estonian Ancient Religion. Speech.] Jurjev: Postimees.

Relve, Henrik 1982. Hiiemets. [Sacred Forests.] Eesti Loodus. Vol. 5, pp. 308-314.

Remmel, Atko 2008. Religioonivastase võitluse korraldusest Nõukogude Eestis. [On the Organisation of Anti-Religious Struggle in Soviet Estonia.] Ajalooline Ajakiri. Vol. 3 (125), pp. 245-280.

Remmel, Mari-Ann 1998. Hiie ase: Hiis Eesti rahvapärimuses. [Hiis Place: Hiis in Estonian Folklore.] Tartu: Eesti Kirjandusmuuseum.

Russow, Balthasar 1967. Liivimaa kroonika. [Livonian Chronicle.] Translated by D. \& H. Stock. Stockholm: Vaba Eesti.

Ränk, Gustav 1935. Muhulaste leedutuledest. [Leedu Fires of the Muhu People.] Offprint from Kaleviste mailt. Tartu: Õpetatud Eesti Selts, pp. 218-224.

Ränk, Gustav 1980. Hiiehobune. [Hiis Horse.] Eesti Teadusliku Seltsi Rootsis aastaraamat / Annales Societatis Litterarum Estonicae in Sveciae, Vol. 8, 1977-1979. Stockholm: Eesti Teaduslik Selts Rootsis, pp. 119-140.

Sild, Olaf 1937. Kirikuvisitatsioonid eestlaste maal vanemast ajast kuni olevikuni. [Church Visitations on the Land of Estonians from the Old Times until the PresentDay.] Tartu: K. Mattiesen.

Sutrop, Urmas 2004. Taarapita - the Great God of the Oeselians. Folklore: Electronic Journal of Folklore. Vol. 26, pp. 27-64.

Talve, Ilmar 1979. Suomen kansankulttuuri: historiallisia päälinjoja. [Finnish Folk Culture: Historical Mainstreams.] Helsinki: Suomalaisen Kirjallisuuden Seura.

Tedre, Ülo 1989. Jakob Hurt 150. Keel ja Kirjandus. Vol. 7, pp. 385-391. 
Torp-Kõivupuu, Marju 2007. Ristipuud Lõuna-Eesti maastikul ja kohapärimuses. [Cross-Signed Trees on South-Estonian Landscape and in Local Lore.] In: H. Valk (ed.) Looduslikud pühapaigad. Väärtused ja kaitse. Õpetatud Eesti Seltsi Toimetised 36. Tartu: Õpetatud Eesti Selts, pp. 289-315.

Urtāns, Juris 2008. Ancient Cult Sites of Semigallia. Zemgales senās kulta vietas. CCC papers, No. 11. Rīga: Nordik.

Vaitkevičius, Vykintas 2004. Studies into the Balts' Sacred Places. BAR International Series, 1228. Oxford: John and Erica Hedges, Ltd.

Valk, Heiki 1995. Lõuna-Eesti XIII-XVII/XVIII sajandi külakalmistud rahvatraditsioonis ja uskumustes. [13th-18th-Century Rural Cemetries from South-Estonia in Folk Tradition and Beliefs.] In: M. Hiiemäe \& M. Kõiva (eds.) Rahvausund tänapäeval. Tartu: Eesti TA Eesti Keele Instituut \& Eesti TA Eesti Kirjandusmuuseum, pp. 454-471.

Valk, Heiki 2007a. Choosing Holy Places. In: R. Haeussler \& A. C. King (eds.) Continuity and Innovation in Religion in the Roman West, Vol. 1. JRA Supplementary Series, No. 67. Portsmouth, RI: JRA, pp. 201-212.

Valk, Heiki 2007b. Looduslikud pühapaigad kui muistised: arheoloogi vaatenurk. [Sacred Natural Places as Archaeological Objects.] In: H. Valk (ed.) Looduslikud pühapaigad. Väärtused ja kaitse. Õpetatud Eesti Seltsi Toimetised, 36, Tartu: Õpetatud Eesti Selts, pp. 135-170.

Valk, Heiki (ed.) 2007c. Looduslikud pühapaigad. Väärtused ja kaitse. [Holy Natural Places. Values and Protection.] Õpetatud Eesti Seltsi Toimetised, 36, Tartu: Õpetatud Eesti Selts.

Valk, Heiki 2009. Sacred Natural Places in Estonia: Regional Aspects. Folklore; Electronic Journal of Folklore. Vol. 42, pp. 45-66.

Vilbaste, Gustav 1947. Vanade kaartide abi muistsete kultusepaikade kindlakstegemisel. [Using Old Maps in Identifying Ancient Cult Places.] Eesti Rahva Muuseumi aastaraamat I (XV). Tartu: Eesti Rahva Muuseum, pp. 157-161.

Viidalepp, Richard 1940. Iseloomustavat Eesti ohvrikividest. [Characteristics of Estonian Offering Stones.] Offprint from journal Eesti Kirjandus, Vols. 10-12. Tartu: Eesti Rahvaluule Arhiiv.

Viidalepp, Richard 1941. Eesti ohvrikivid. Magistritöö. [Estonian Offering Stones. MA thesis.] Manuscript in the Library of the University of Tartu. Tartu: University of Tartu.

Viires, Ants 1975. Puud ja inimesed: puude osast eesti rahvuskultuuris. [Trees and People: The Role of Trees in Estonian Folk Culture.] Tallinn: Valgus.

Viires, Ants 1990. Taara avita. [Taara Help.] Looming. Vol. 10, pp. 1410-1421.

Viires, Ants 2001[1991]. Muistsed jumalad ühiskonna teenistuses. [Ancient Gods in the Service of Society.] In: A. Viires (ed.) Kultuur ja traditsioon. Tartu: Ilmamaa, pp. 217-225. 